Justyna Łupińska*

\title{
SKUTKI WPROWADZENIA PODATKU BANKOWEGO W POLSCE W KONTEKŚCIE MOŻLIWOŚCI OGRANICZENIA NEGATYWNYCH EFEKTÓW ZEWNĘTRZNYCH GENEROWANYCH PRZEZ KRAJOWY SEKTOR BANKOWY
}

\section{Wprowadzenie}

Banki, postrzegane pierwotnie jako instytucje ograniczające skutki nieefektywności rynków finansowych, stały się przed blisko 10 laty istotnym źródłem negatywnych efektów zewnętrznych, których materializacja jest postrzegana jako jedna z głównych przesłanek wybuchu drugiego największego kryzysu finansowego ostatniego stulecia. Poprzez globalne rynki finansowe, interakcje z realną sferą gospodarki oraz poprzez kanał deficytu finansów publicznych kryzys ten uzyskał głęboki wymiar społeczny, dotykając również mieszkańców krajów, których gospodarki posiadały pierwotnie zdrowe fundamenty finansowe i makroekonomiczne. W tym kontekście na forum międzynarodowym (m.in. w ramach grupy G20 oraz w otoczeniu instytucjonalnym Wspólnoty Europejskiej), a także na poziomie poszczególnych krajów zaczęto rozważać, a następnie przyjmować rozwiązania legislacyjne pozwalające na silniejsze, bezpośrednie oddziaływanie państwa na podmioty sektora bankowego. Jednym z takich rozwiązań stał się podatek bankowy, który na początku 2016 r. wprowadzony został również w Polsce.

Mając na uwadze blisko dwa lata, które upłynęły od wprowadzenia przedmiotowego podatku w Polsce, autorka niniejszego artykułu stara się na bazie analizy danych empirycznych odpowiedzieć na pytanie, na ile we wdrożonym w kraju wariancie ma on wyłącznie charakter fiskalny, a na ile za jego pomocą możliwa jest moderacja skali negatywnych efektów zewnętrznych generowanych przez krajowy sektor bankowy w sytuacji, w której podatnicy tej daniny przyjmą szereg rozwiązań

* Doktorantka Kolegium Zarządzania i Finansów, Szkoła Główna Handlowa w Warszawie. 
optymalizujących wysokość zobowiązań oraz będą dążyć do przerzucenia (części) jego kosztu na swoich klientów. Postawiona hipoteza badawcza brzmi więc następująco: wprowadzona w Polsce charakterystyka i konstrukcja podatku bankowego powoduje, że danina ta ma przede wszystkim wymiar fiskalny, jednocześnie jednak sposób określenia podstawy opodatkowania opartej o wartość aktywów banków (z możliwością odliczania wybranych pozycji aktywów i pasywów) umożliwia częściową internalizację negatywnych efektów zewnętrznych generowanych przez banki. Jako hipotezę pomocniczą przyjęto, że działania banków z zakresu optymalizacji podatkowej prowadzą do ograniczenia skali internalizacji negatywnych efektów zewnętrznych, a w niektórych przypadkach mogą wręcz prowadzić do powstania samoistnych negatywnych efektów zewnętrznych.

Głównym celem artykułu jest przedstawienie możliwości internalizacji negatywnych efektów zewnętrznych generowanych przez banki za pośrednictwem wprowadzonego w Polsce na początku 2016 r. podatku bankowego. Przeprowadzone na potrzeby artykułu badania uwzględniają adaptacyjną odpowiedź banków na wprowadzoną daninę (optymalizacja podatkowa) oraz łączne skutki tejże odpowiedzi poprzez grupową aktywność m.in. na rynku międzybankowym oraz rynku krajowego długu skarbowego. Empiryczna ocena skutków wprowadzenia podatku bankowego oraz ewaluacja jego potencjału do internalizacji negatywnych efektów zewnętrznych została dokonana na podstawie danych statystycznych z lat 2015-2017.

\section{Nieefektywności rynków finansowych i negatywne efekty zewnętrzne jako przyczyny kryzysu finansowego 2007+}

Zgodnie z teoriami opracowanymi w latach 70. XX w. m.in. przez Rothshilda i Stiglitza ${ }^{1}$ oraz Lelanda i Pyle ${ }^{2}$ jedną z głównych przesłanek powstania instytucji finansowych, w szczególności banków, była chęć ograniczenia niedoskonałości rynku wynikających $z$ asymetrii informacji oraz nadmiernych kosztów transakcyjnych. Efektem pracy zatrudnionych w bankach profesjonalistów (m.in. kadry zarządczej i analityków kredytowych) jest obniżenie w ramach tych instytucji kosztu oceny wypłacalności potencjalnych kredytobiorców, a tym samym znaczące ograniczenie kosztów

\footnotetext{
1 M. Rothschild, J.E. Stiglitz, Equilibrium in competitive insurance markets: An essay on the economics of imperfect information, „Quarterly Journal of Economics” 95, 1976, s. 629-649.

2 H.E. Leland, D.H. Pyle, Informational asymmetries, financial structure, and financial intermediation, „The Journal of Finance” 32, 1977, s. 371-387.
} 
zawarcia kontraktu kredytowego, zapewniające efektywne pośrednictwo finansowe pomiędzy wierzycielami banku a podmiotami poszukującymi źródeł zewnętrznego finansowania zdolnymi do spłaty zaciągniętych zobowiązań

Przejawiające się w aktywności banków niedoskonałości rynkowe prowadzą do materializacji różnorakich rodzajów ryzyka (m.in. kredytowego, płynności, rynkowego), które propagowane jest na zewnątrz instytucji, stanowiąc zewnętrzny koszt ich funkcjonowania. W przypadku jednoczesnego wystąpienia negatywnych efektów zewnętrznych $\mathrm{w}$ wielu bankach rynki finansowe stają się środowiskiem transmisji ryzyka do pozostałych, początkowo „zdrowych” instytucji, co staje się zarzewiem ryzyka systemowego prowadzącego do destabilizacji systemu finansowego ${ }^{4}$. Jeśli do ratowania instytucji finansowych o znaczącej wartości „toksycznych” aktywów na szeroką skalę wykorzystywane są środki podatników, jako następstwo kryzysu finansowego pojawia się kryzys finansów publicznych ${ }^{5}$, a spowodowane nim cięcia bieżących wydatków budżetowych przy jednoczesnym wzroście obciążeń podatkowych powodują daleko idące implikacje społeczne i polityczne $e^{6}$.

Specyfika rozprzestrzeniania się ryzyka w sektorze bankowym oraz przyczynowo-skutkowy charakter relacji pomiędzy kryzysami finansowymi i kryzysami finansów publicznych stały się przesłanką do wprowadzania przez poszczególne państwa regulacjii polityk składających się na instytucjonalny system zakazów oraz bodźców bezpośrednio oddziałujących na sposób funkcjonowania banków. Wśród rozważanych instrumentów realizacji polityk oddziaływania przez państwo na sektor bankowy, które miałyby stanowić narzędzie internalizacji negatywnych efektów zewnętrznych, znalazł się podatek bankowy (bank levy) ${ }^{7}$. Artykuł ma na celu zbadanie, na ile wariant podatku bankowego wprowadzonego w Polsce może zostać uznany jako środek internalizacji negatywnych efektów zewnętrznych generowanych przez instytucje finansowe, a na ile jest to narzędzie służące do powiększania fiskalnych przychodów państwa.

3 G. Gorton, A. Winton, Financial Intermediation, „NBER Working Paper” 8928, Cambridge, MA 2002.

4 IMF, Containing systemic risks and restoring Financial soundness, Global Financial Stability Report, April 2008.

5 P.R. Lane, The European sovereign debt crisis, „Journal of Economic Perspectives” 26(3), 2012, s. 49-68.

6 S. Owsiak, Społeczny wymiar kryzysu - lekcja dla przyszłości, „Biuletyn PTE” nr 2, 2012.

7 F.A. Schweikhard, M. Wahrenburg, The internalization of systemic risk: An analysis of bank levy schemes, [materiał zaprezentowany na konferencji EFA], Gothenburg 2013. 


\section{Przegląd literatury}

Kontrybucja na rzecz stabilności finansowej (financial stability contribution) uzależniona od wartości sumy bilansowej banków (aktywów bądź pasywów) zaproponowana została po raz pierwszy w raporcie MFW z 2010 r. ${ }^{8}$ jako sposób na stworzenie zharmonizowanego funduszu sanacji niewypłacalnych instytucji w przypadku wystąpienia przyszłych kryzysów finansowych. Kilka miesięcy po poddaniu przedmiotowego raportu dyskusji podczas czerwcowego szczytu grupy G20 w Toronto opcja wprowadzenia jednolitego podatku bankowego w krajach należących do tej grupy przestała być przedmiotem rozważań. Jednocześnie poszczególne kraje G20 nie zarzuciły prac nad wprowadzeniem tego rodzaju daniny. Równolegle wprowadzenie podatku bankowego stało się przedmiotem analiz instytucji Wspólnoty Europejskiej, przede wszystkim Komisji Europejskiej.

Na gruncie krajowym jedne z pierwszych analiz dotyczących zasadności wprowadzenia podatku bankowego przeprowadził Narodowy Bank Polski ${ }^{10}$ oraz Forum Obywatelskiego Rozwoju ${ }^{11}$. Możliwe warianty potencjalnego wprowadzenia podatku bankowego w Polsce przedstawili z kolei Juszczyk i Snarski ${ }^{12}$. Implementacja podatku bankowego w krajowym ustawodawstwie ${ }^{13}$ otworzyła możliwość empirycznej analizy skutków oddziaływania przedmiotowej daniny na sektor bankowy. Ciekawym przyczynkiem do dyskusji na ostatni ze wskazanych tematów są prace Gajewskiego ${ }^{14}$ bazujące w znacznej mierze na krytycznej analizie źródłowego aktu prawnego uchwalonego przez Sejm oraz opracowanie Malinowskiego ${ }^{15}$. Opinie dotyczące wad i zalet

8 IMF, A Fair and substantial contribution by the financial sector, Interim Report for the G20, April 2010.

9 EC, Commission outlines vision for taxing the financial sector, http://europa.eu/rapid/press-release IP-10-1298_en.htm?locale=en, 2010 [dostęp 28.03.2018]; EC, Taxation of the financial sector, Commission Staff Working Documents, 2010; EC, Communication on taxation of the financial sector, Communications of the European Commission, 2010.

10 NBP, Wybrane aspekty dodatkowego opodatkowania banków w kontekście debaty na forum Unii Europejskiej, 2010, https://www.nbp.pl/systemfinansowy/banki_aspekty_opodatkowania.pdf [dostęp 29.03.2018].

11 FOR, Dlaczego nie należy nakładać podatku na aktywa banków?, „Analiza FOR” nr 5, 2010, https:// for.org.pl/pl/a/1438, Analiza-52010-Dlaczego-nie-nalezy-nakladac-podatku-na-aktywa-bankow [dostęp 29.03.2018].

12 S. Juszczyk, P. Snarski, Przegląd potencjalnych podatków i opłat nakładanych na banki w obliczu globalnego kryzysu gospodarczego, „Zeszyty Naukowe SGGW w Warszawie”, „Ekonomika i Organizacja Gospodarki Żywnościowej” nr 93, 2011.

13 Ustawa z dnia 15 stycznia 2016 r. o podatku od niektórych instytucji finansowych, DzU 2016, poz. 68.

14 D.J. Gajewski, Podatek bankowy a zjawisko unikania opodatkowania, „Przegląd Ustawodawstwa Gospodarczego" 6(816), 2016; idem, Podatek bankowy w Polsce - wady i zalety, „Analizy i Studia CASP” 1(1), 2016, s. $1-24$.

15 D.M. Malinowski, Podatek bankowy - podstawowe założenia, instytucje i skutki jego wprowadzenia, „Przegląd Podatkowy” nr 2(298), 2016, s. 3-4. 
krajowej implementacji podatku bankowego przedstawił Furman ${ }^{16}$. Podejście bazujące na analizie ilościowej odnoszącej się do wpływu podatku bankowego na akcję kredytową krajowych banków przedstawili z kolei Borowski, Jaworski i Tymoczko ${ }^{17}$. Warto również zwrócić uwagę na publikowany cyklicznie przez Komisję Nadzoru Finansowego materiał oceniający podstawowe skutki wpływu podatku bankowego na sytuację krajowych banków komercyjnych ${ }^{18}$. Materiał ten stanowi punkt wyjścia do analiz przeprowadzonych przez autorkę niniejszej pracy.

\section{Ogólna idea podatku bankowego}

Weryfikacja hipotezy badawczej postawionej przez autorkę artykułu wymaga rozważenia, jakie są pożądane cechy i konstrukcja podatku bankowego (podstawa opodatkowania i podlegający daninie podatnicy) pozwalające na internalizację i ograniczenie negatywnych efektów zewnętrznych generowanych przez instytucje sektora bankowego poprzez ograniczenie skłonności banków do podejmowania nadmiernego ryzyka przerzucanego następnie na podmioty zewnętrzne, przy jednoczesnym zachowaniu przez banki zdolności do zyskownego świadczenia usług pośrednictwa finansowego oraz utrzymaniu na rozsądnym poziomie kosztów tychże usług dla klientów końcowych. Innymi słowy, wprowadzone rozwiązanie prawne w tym zakresie powinno się charakteryzować:

1) możliwością ograniczenia negatywnych efektów zewnętrznych, m.in. asymetrii informacji, problemu agencji, hazardu moralnego, negatywnej selekcji, a także generowania ryzyka wynikającego z konstrukcji schematów wynagradzania kadry menedżerskiej oraz proliferacji ryzyka systemowego, przy jednoczesnym ograniczeniu możliwości generowania dodatkowych zniekształceń spowodowanych wprowadzeniem podatku;

2) brakiem zniekształcania oddziałujących na banki bodźców rynkowych pozwalających na efektywną alokację środków finansowych pozyskanych od deponentów;

3) odpornością na agresywne metody optymalizacji podatkowej prowadzące do materializacji niestabilności systemu finansowego;

16 Ł. Furman, Podatek od aktywów instytucji finansowych: zagrożenia czy korzyści, „Zeszyty Naukowe Małopolskiej Wyższej Szkoły Ekonomicznej w Tarnowie" nr 33(1), 2017.

17 J. Borowski, K. Jaworski, D. Tymoczko, Wptyw podatku bankowego w Polsce na kredyt dla sektora niefinansowego, „Studia Ekonomiczne. Zeszyty Naukowe UE w Katowicach” nr 287, 2016.

$18 \mathrm{KNF}$, Syntetyczna informacja na temat wptywu podatku od niektórych instytucji finansowych na sytuację banków komercyjnych, 2017, https://www.knf.gov.pl/knf/pl/komponenty/img/Opracowanie_podatek_ bankowy_17-08-2017_58323.pdf [dostęp 28.03.2018]. 
4) możliwością jednoczesnej realizacji funkcji opisanej w punkcie 1 przy zachowaniu warunku opisanego w punkcie 2, przy jednoczesnym wypełnieniu spodziewanych fiskalnych efektów wprowadzonej daniny.

Ostateczna charakterystyka podatku bankowego w dużej mierze zależy od konstrukcji przyjętej przez ustawodawcę. Analizując rozwiązania proponowane w odpowiedzi na kryzysy finansowe, począwszy od drugiej połowy ubiegłego wieku, w zakresie podstawy opodatkowania wyróżnić można w tym zakresie trzy podstawowe warianty:

1) Tobinowski podatek od transakcji realizowanych na rynkach finansowych (Financial Transactions Tax - FTT);

2) podatek od efektów aktywności finansowej (Financial Activity Effects Tax - FAET), gdzie najistotniejszą kategorią podlegającą opodatkowaniu jest zysk wypracowany przez instytucje finansowe;

3) podatek od skali aktywności finansowej (Financial Activity Scale Tax - FAST), w ramach którego danina wnoszona przez instytucje finansowe zależy głównie od wartości ich aktywów bądź pasywów.

Podatek w wariancie FAT jest de facto podatkiem obrotowym. W swoim podstawowym zakresie dotyczy on wyłącznie operacji kupna/sprzedaży akcji i obligacji i jest mało przydatny z punktu widzenia możliwości eliminacji negatywnych efektów zewnętrznych. Przyjęcie szerokiego katalogu transakcji podlegających opodatkowaniu (m.in. aktywność banków na rynkach walutowych i/lub instrumentów pochodnych) prowadzi do zwiększenia kosztów transakcyjnych często zawieranych operacji spekulacyjnych, a tym samym powinno ograniczać zmienność cen instrumentów będących przedmiotem obrotu, zwiększać stabilność tych rynków i przyczyniać się do ograniczenia ekspozycji instytucji finansowych na ryzyko związanych z uczestnictwem w tych rynkach.

W przypadku drugiego rodzaju konstrukcji podstawy opodatkowania (wyrażonych w pieniądzu efektów działalności finansowej) rozważane są trzy możliwe rozwiązania:

1) opodatkowanie wartości wypracowanego przez instytucję finansową zysku powiększonej o sumę wynagrodzeń kadry menedżerskiej banku przekraczających przyjęty przez ustawodawcę pułap;

2) opodatkowanie wartości wypracowanego przez instytucję finansową zysku przekraczającego określony pułap powiększonej o sumę wynagrodzeń kadry menedżerskiej również przekraczających określoną wartość progową;

3) opodatkowanie podstawy określonej jak w punkcie pierwszym lub drugim, jednak pomniejszonej o wartość wydatków instytucji finansowej na inwestycje. Wszystkie trzy zaprezentowane propozycje są ukierunkowane na „karanie” instytucji finansowych za podejmowanie nadmiernego ryzyka oraz budowanie schematów 
wynagradzania pozwalających kadrze menedżerskiej na uzyskiwanie ponadprzeciętnych przychodów w efekcie agresywnego inwestowania środków powierzonych przez klientów, ograniczając tym samym ryzyko wystąpienia hazardu moralnego i efektu domina.

W świetle opisanych zalet i wad dwóch pierwszych rozwiązań w zakresie konstrukcji podstawy opodatkowania warto przyjrzeć się rozwiązaniu polegającemu na opodatkowaniu skali działalności instytucji finansowych. Wśród wielu możliwych rozwiązań praktycznych rozważmy trzy warianty bazujące na raportowanych przez banki kategoriach bilansowych:

1) opodatkowanie sumy aktywów bądź pasywów instytucji finansowych;

2) opodatkowanie zobowiązań instytucji finansowych;

3) opodatkowanie sumy aktywów/pasywów pomniejszonych o wysokość kapitału własnego, depozytów oraz należności z tytułu nabycia skarbowych papierów wartościowych.

Niewątpliwą zaletą wymienionych sposobów obliczenia podstawy opodatkowania jest relatywna łatwość zdefiniowania kategorii objętych daniną. Ponadto pozwalają one na ograniczenie czynników bezpośrednio przekładających się na skalę efektów zewnętrznych oddziałujących na otoczenie instytucji finansowych (ograniczenie wpływu reguły too-big-too fail).

Podsumowując, trudno jest znaleźć rozwiązanie w zakresie konstrukcji podatku bankowego, które mogłoby jednoznacznie stanowić optymalny sposób internalizacji negatywnych efektów zewnętrznych, a z drugiej strony być odpornym na unikanie przez instytucje płacenia tej daniny poprzez kreatywny sposób prowadzenia księgowości lub też przerzucanie jej kosztu na klientów. W dalszej części pracy analizie poddane zostanie rozwiązanie przyjęte $\mathrm{w}$ Polsce bazujące na podejściu FAST $\mathrm{w}$ wariancie dotyczącym wartości aktywów instytucji podatkowych, uwzględniającym liczne odliczenia od podstawy opodatkowania (m.in. wartość funduszy własnych i należności wynikających z zakupu obligacji skarbowych).

\section{Podatek bankowy w Polsce}

Podatek od niektórych instytucji finansowych, zwany potocznie podatkiem bankowym, został wprowadzony w Polsce ustawą ze stycznia 2016 r., która weszła w życie z ponad dwutygodniowym vacatio legis ${ }^{19}$. Pierwszy projekt ustawy wprowadzającej

19 Ustawa z dnia 15 stycznia 2016 r. ..., op.cit. 
tego rodzaju daninę obciążającą banki proporcjonalnie do wartości ich aktywów (stawka w wysokości 0,39\%) złożony został bowiem w Sejmie już 2010 r., a kolejną analogiczną inicjatywę (ze stawką 0,25\% liczoną również od wartości aktywów podmiotów objętych podatkiem) podjęto rok później ${ }^{20}$. W obu przypadkach wpływy z podatku w całości trafić miały do budżetu państwa. Konstrukcja wprowadzonego ustawą ze stycznia $2016 \mathrm{r}$. podatku przedstawia się następująco:

1) W zakresie podmiotowym podatnikami tego podatku są:

a) krajowe banki (z wyłączeniem Banku Gospodarstwa Krajowego SA), oddziały banków zagranicznych oraz oddziały instytucji kredytowych, których wartość aktywów przekracza 4 mld zł;

b) spółdzielcze kasy oszczędnościowo-kredytowe, których wartość aktywów przekracza 4 mld zł;

c) krajowe zakłady ubezpieczeń, reasekuracji oraz oddziały zagranicznych zakładów ubezpieczeń i reasekuracji, których wartość aktywów przekracza 2 mld zł;

d) instytucje pożyczkowe o wartości aktywów przekraczających $200 \mathrm{mln}$ zł.

2) W zakresie przedmiotowym opodatkowaniu podlega nadwyżka sumy wartości aktywów podatnika, wynikająca z zestawienia obrotów i sald, określona na ostatni dzień miesiąca według zapisów na kontach księgi głównej, przy czym w przypadku banków oraz oddziałów banków zagranicznych i oddziałów instytucji kredytowych podstawa opodatkowania pomniejszana jest o wartość:

a) funduszy własnych;

b) skarbowych papierów wartościowych;

c) aktywów stanowiących zabezpieczenie kredytu refinansowego udzielonego przez NBP;

d) środków zgromadzonych przez bank zrzeszający na rachunkach zrzeszonych banków spółdzielczych.

3) Stawka podatku wynosi $0,44 \%$ podstawy opodatkowania w skali roku (odpowiednio $0,0366 \%$ miesięcznie), podatek nie stanowi kosztu uzyskania przychodu w rozumieniu ustawy o podatku dochodowym od osób prawnych (CIT), w związku z czym stawka efektywna wynosi $0,54 \% \mathrm{w}$ skali roku.

4) Obowiązuje samookreślenie zobowiązania podatkowego: podmioty podlegające opodatkowaniu zobowiązane są do samodzielnego obliczenia i złożenia do naczelnika właściwego urzędu skarbowego deklaracji wskazującej wysokość tego zobowiązania, a ponadto odpowiedniej jego kwoty do uiszczenia na rachunek wspomnianego urzędu skarbowego do 25 dnia miesiąca następującego po miesiącu, którego podatek dotyczy.

20 Sejm, Proces legislacyjny Sejmu VI kadencji, http://orka.sejm.gov.pl/proc6.nsf [dostęp 4.04.2018]. 
Z punktu widzenia rozważań dotyczących możliwości internalizacji negatywnych efektów zewnętrznych za pomocą podatku bankowego należy jednocześnie dodać, że $\mathrm{w}$ zaimplementowanej postaci przychody państwa $\mathrm{z}$ daniny wniesionej przez określone powyżej instytucje finansowe trafiają w pełnej wysokości do budżetu państwa.

\section{Internalizacja negatywnych efektów zewnętrznych a przerzucalność zobowiązań wynikających z wprowadzenia podatku bankowego}

Istotnym warunkiem możliwości internalizacji negatywnych efektów zewnętrznych za pośrednictwem danego instrumentu polityki państwa jest ograniczona możliwość uchylania się adresatów instrumentu od ponoszenia konsekwencji związanych z jego wprowadzeniem. Tymczasem instytucje finansowe, działając od wielu lat w środowisku podlegającym jednym z najdalej idących regulacji, potrafią skutecznie unikać skutków ich wprowadzenia poprzez liczne „innowacje” dotyczące modelu prowadzenia działalności gospodarczej. W przypadku rozważanego instrumentu, podatku skonstruowanego zgodnie z opisanym powyżej katalogiem zasad, jednym ze sposobów na ograniczenie wysokości zobowiązań instytucji finansowych jest przesunięcie wynikających z jego wprowadzenia obciążeń na inne podmioty, co w literaturze nosi miano przerzucalności podatku ${ }^{21}$.

Jednym z prostszych sposobów na ograniczenie wysokości zobowiązania banku wynikającego $\mathrm{z}$ analizowanego podatku jest możliwość zmniejszenia podstawy opodatkowania poprzez wykazanie na ostatni dzień miesiąca na kontach księgi głównej skarbowych papierów wartościowych o wartości możliwie wysokiej w stosunku do całkowitej wartości aktywów, na które w pozostałej części składają się głównie kredyty. Można jedynie domniemywać, że wśród intencji ustawodawcy wprowadzającego możliwość odliczenia od podstawy opodatkowania wartości papierów skarbowych było obniżenie ekspozycji banków na ryzyko (alokacja środków pozyskanych od deponentów w relatywnie bezpieczne instrumenty finansowe) oraz zapewnienie bardziej stabilnego sposobu finansowania długu publicznego (zakup długu przez przewidywanych inwestorów będących krajowymi rezydentami). Przyjmując tę perspektywę, należy stwierdzić, że podatek bankowy może mieć wpływ na ograniczenie skali efektów zewnętrznych.

21 D.J. Gajewski, Podatek bankowy w Polsce..., op.cit. 
Rozwiązaniem pozwalającym na kształtowanie do celów podatkowych wartości aktywów krajowych banków posiadających za granicą oddziały bądź spółki powiązane kapitałowo (np. spółki-matki) jest możliwość realokacji części portfela kredytowego poza obszar lokalnej jurysdykcji. Zasadność finansowa tego rodzaju operacji występuje w przypadku umów kredytowych znacznej wartości, można się więc spodziewać, że rozwiązanie to dotyczyć będzie kontraktów zawieranych przez banki ze średnimi i dużymi podmiotami, jedynie w wyjątkowych sytuacjach dotyczyć może ono umów, których stroną są osoby fizyczne. Niemniej jednak tego typu działania pozwalają na wyłączenie z podstawy opodatkowania części najbardziej lukratywnych (przynoszących najwyższą pod względem marży odsetkowej) należności banków, przyczyniając się dodatkowo do obniżenia ich wyniku odsetkowego, a tym samym do obniżenia podstawy podatku dochodowego od osób prawnych (CIT). Dodatkowo jako pochodną praktycznego wykorzystania powyższego rozwiązania należy rozważyć: - ograniczenie akcji kredytowej krajowych banków, w szczególności w zakresie umów zawieranych z klientami korporacyjnymi;

- w przypadku udzielania kredytów indeksowanych walutami obcymi krajowym podmiotom gospodarczym uzyskującym większość przychodów w krajowej walucie narażenie tych podmiotów na dodatkowe ryzyko finansowe związane z wahaniami wartości kredytu uzależnionej od charakteryzującego się znaczną zmiennością kursu walutowego oraz wynikające z uzależnienia tych podmiotów od finansowania przez krajowe instytucje o niekiedy znacznie niższej efektywnej wypłacalności.

Ponadto opisane rozwiązanie może prowadzić do powstania swoistej przewagi konkurencyjnej w zakresie możliwości prowadzenia akcji kredytowej obciążonej niższym narzutem podatkowym przez podmioty posiadające za granicą spółki powiązane kapitałowo bądź oddziały. Występowanie podobnego zjawiska można było zaobserwować na początku obecnego wieku w zakresie udzielanych przez krajowe banki kredytów denominowanych w walutach obcych, które zabezpieczane były przez zagraniczne spółki-matki na znacznie korzystniejszych zasadach, niż mogły to uczynić podmioty działające wyłącznie w Polsce.

Depozyty zebrane przez banki na rynku międzybankowym stanowią dodatkową pulę płynnych środków. Mogą one zostać przez bank zagospodarowane czterema głównymi sposobami: poprzez udzielenie kredytu, poprzez złożenie depozytu w innym banku lub w NBP, poprzez zakup papierów wartościowych lub też poprzez zakup innych instrumentów finansowych. W przypadku przyjęcia w ostatnim dniu miesiąca depozytu typu overnight rzeczywisty jego koszt dla banku rośnie o 0,0366 pkt. proc., co w większości przypadków czyni tego rodzaju operację nieopłacalną dla banku. Instytucje te $\mathrm{w}$ ostatnim dniu miesiąca (i bezpośrednio przed tym terminem) mają 
więc silny bodziec do oferowania znacznie niższych stawek oprocentowania depozytów, bądź wręcz wstrzymywania się z ich przyjmowaniem. Jednocześnie spłaszczeniu ulega pozostała część krzywej rentowności depozytów (przede wszystkim w jej środkowym segmencie), a obroty na rynku międzybankowym mogą się cyklicznie wahać w rytm miesięcznego cyklu określenia podstawy podatku bankowego, prowadząc do jego destabilizacji.

\section{Efekty wprowadzenia podatku bankowego w Polsce w kontekście internalizacji negatywnych efektów zewnętrznych}

Po analizie konstrukcji podatku bankowego wprowadzonego w Polsce oraz teoretycznych aspektów jego oddziaływania na krajowy sektor bankowy, w tym po rozważeniu jego potencjału w zakresie internalizacji negatywnych efektów zewnętrznych, autorka artykułu chciałaby przedstawić wyniki analizy empirycznej dotyczącej praktycznych skutków wdrożenia przedmiotowego podatku. W ramach podjętego badania rozważone zostały dwa zasadnicze aspekty implementacji podatku bankowego w horyzoncie czasowym obejmującym okres ostatnich trzech lat:

a) efektywność poboru podatku bankowego oraz zdolność do pokrycia ewentualnych kosztów interwencji państwa w odpowiedzi na materializację kryzysu sektora bankowego odpowiadającego siłą kryzysowi 2007+;

b) zdolność banków do ograniczenia wpływu wprowadzenia podatku bankowego na realizowany przez nie model biznesowy w zakresie:

- możliwości bezpośredniego przerzucenia kosztu podatku na klientów banku,

- optymalizacji wartości i struktury aktywów, pasywów oraz pozycji pozabilansowych,

- realizacji programów naprawczych.

Przechodząc do opisu empirycznej części analizy, raz jeszcze należy podkreślić, że konstrukcja podatku bankowego (uzyskane z jego tytułu wpływy zasilają bezpośrednio budżet państwa) jednoznacznie wskazuje, że bezpośrednią przesłanką do jego wprowadzenia było osiągnięcie celu fiskalnego poprzez redystrybucję przychodów uzyskiwanych przez banki do adresatów wprowadzanych rozwiązań związanych $\mathrm{z}$ realizacją nowej polityki społecznej. Warto jednak sprawdzić, w jaki sposób w dwuletniej perspektywie obowiązywania podatku bankowego kształtowała się efektywność jego poboru, a ewentualne przychody mogłyby zrównoważyć ewentualne wydatki związane z kosztem stabilizacji sektora bankowego, pozwalając na pośrednią (przy 
udziale państwa) internalizację negatywnych efektów zewnętrznych generowanych przez sektor bankowy.

W dalszej analizie posłużono się danymi pochodzącymi z Ministerstwa Finansów $^{22}$. Wskaźnik efektywności poboru podatku został określony jako relacja spodziewanych wpływów z podatku bankowego w poszczególnych miesiącach założona pierwotnie przez ustawodawcę (w 2016 r.) w stosunku do rzeczywistych wpływów. Z kolei na potrzeby zbadania możliwości pokrycia przychodami z podatku bankowego ewentualnych kosztów sanacji sektora bankowego przyjęto za Amaglobelim $\mathrm{i}$ in. ${ }^{23}$ na poziomie $25 \% \mathrm{PKB}$.

Rysunek 1. Wskaźnik efektywności poboru podatku w latach 2016-2017 (w \%)

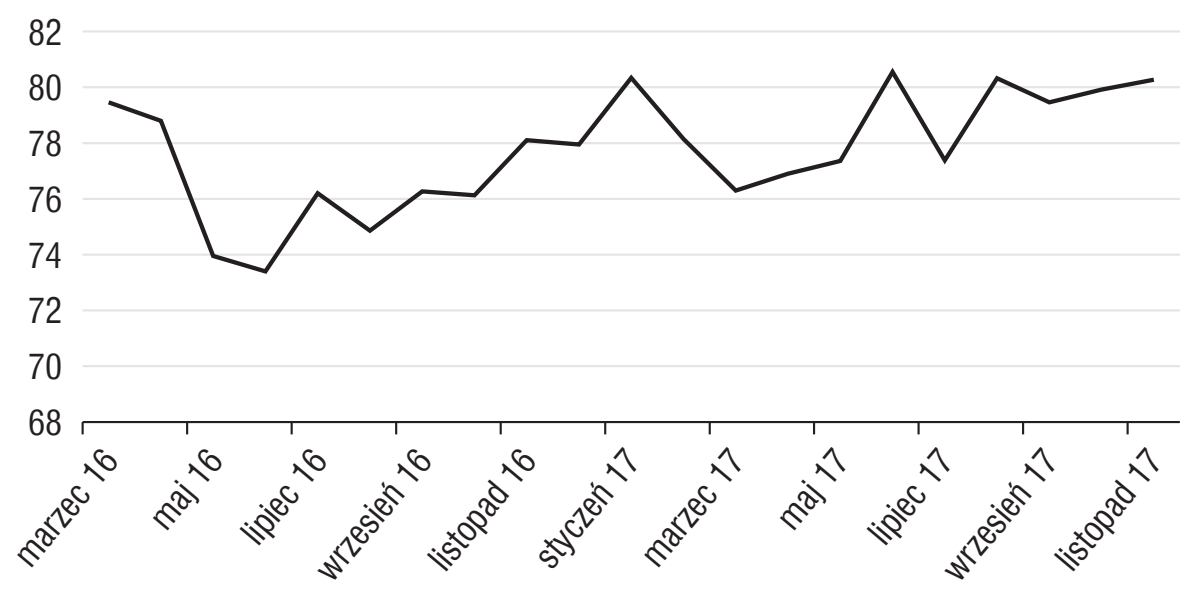

Źródło: MF.

Jak wynika z rysunku $1 \mathrm{w}$ ciągu ostatnich dwóch lat efektywność poboru podatku bankowego kształtowała się na poziomie $75-80 \%$ wartości założonej pierwotnie w ustawie wprowadzającej tę daninę w 2016 r. Można zauważyć rosnący trend tego wskaźnika, jednocześnie należy zwrócić uwagę na równoczesny wzrost nominalnej wartości całkowitej sumy bilansowej podmiotów podlegających opodatkowaniu. $\mathrm{W}$ związku z powyższym można założyć, że proces poboru podatku bankowego tylko w części odpowiadał przewidywaniom ustawodawcy. Ponadto należy zwrócić uwagę, że łączna kwota podatku wpłaconego w 2016 r. (począwszy od marca przedmiotowego roku) przez instytucje finansowe nim objęte wynosiła około 3,5 mld zł, co w porównaniu z potencjalnymi kosztami kryzysu kształtującymi się na poziomie

22 MF, Sprawozdanie operatywne z wykonania budżetu państwa za styczeń-grudzień 2016 r., Warszawa 2016; MF, Sprawozdanie operatywne z wykonania budżetu państwa za styczeń-grudzień 2016 r., Warszawa 2017.

23 D. Amaglobeli et al., From systemic banking crises to fiscal costs: risk factors, „IMF Working Paper” No. 166, 2015. 
około 450 mld zł stanowi jedynie około $0,75 \%$ niezbędnej potencjalnie kwoty. Trudno więc obronić twierdzenie, że podatek bankowy może być skutecznym pośrednim instrumentem internalizacji negatywnych efektów zewnętrznych generowanych przez system finansowy.

Perspektywa wprowadzenie podatku bankowego stała się dla banków niewątpliwie bodźcem do poszukiwania sposobu przerzucenia kosztów jego wprowadzenia na ich klientów. Jak wynika $z$ danych publikowanych przez NBP $w$ ramach statystyki stóp procentowych (rys. 2), pomiędzy styczniem 2015 r. a styczniem 2018 r. średnie oprocentowanie nowych i renegocjowanych umów depozytowych spadło około 30\%, a średnie oprocentowanie nowych i renegocjowanych umów kredytowych o blisko $12 \%$, jednocześnie średnia marża odsetkowa pozostała na niemal niezmienionym poziomie (spadek o 3\%). Można więc wnioskować, że zachowując dochód odsetkowy w teoretycznie niesprzyjającym otoczeniu konkurencyjnym oraz przy niskich stopach procentowych banku centralnego na niemal niezmienionym poziomie, bankom udało się przerzucić przynajmniej w części koszty wprowadzenia podatku na swoich klientów.

Rysunek 2. Średnie oprocentowanie nowych i renegocjowanych umów złotowych (depozytowych i kredytowych) od stycznia 2015 r. do lutego 2018 r. (w \%)

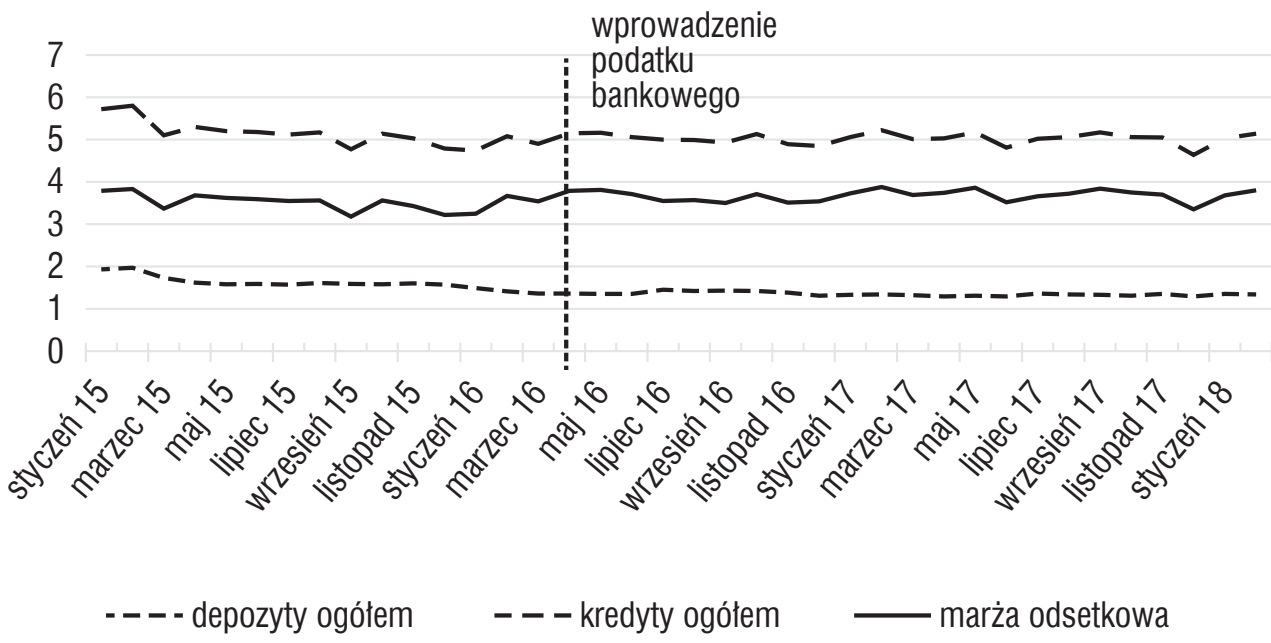

Źródło: NBP.

Wskazaną powyżej zdolność banków do ograniczenia wpływu skutków wprowadzenia podatkowego na rentowność prowadzonej przez nie działalności potwierdza również analiza wyników sektora bankowego przeprowadzona na podstawie danych publikowanych przez Komisję Nadzoru Finansowego (rys. 3). W ciągu całego 2017 r. działającym w Polsce bankom komercyjnym udało się uzyskać wynik z podstawowej działalności na poziomie o blisko 10\% wyższym niż w 2015 r., co pozwoliło 
na wygenerowanie ostatecznego zysku netto w 2017 r. na poziomie o blisko $10 \%$ niższym niż dwa lata wstecz.

Rysunek 3. Miesięczne wyniki finansowe krajowych banków komercyjnych działających z oddziałami zagranicznymi za lata 2015-2017 (z wyłączeniem zdarzeń nadzwyczajnych) (w mln zł)

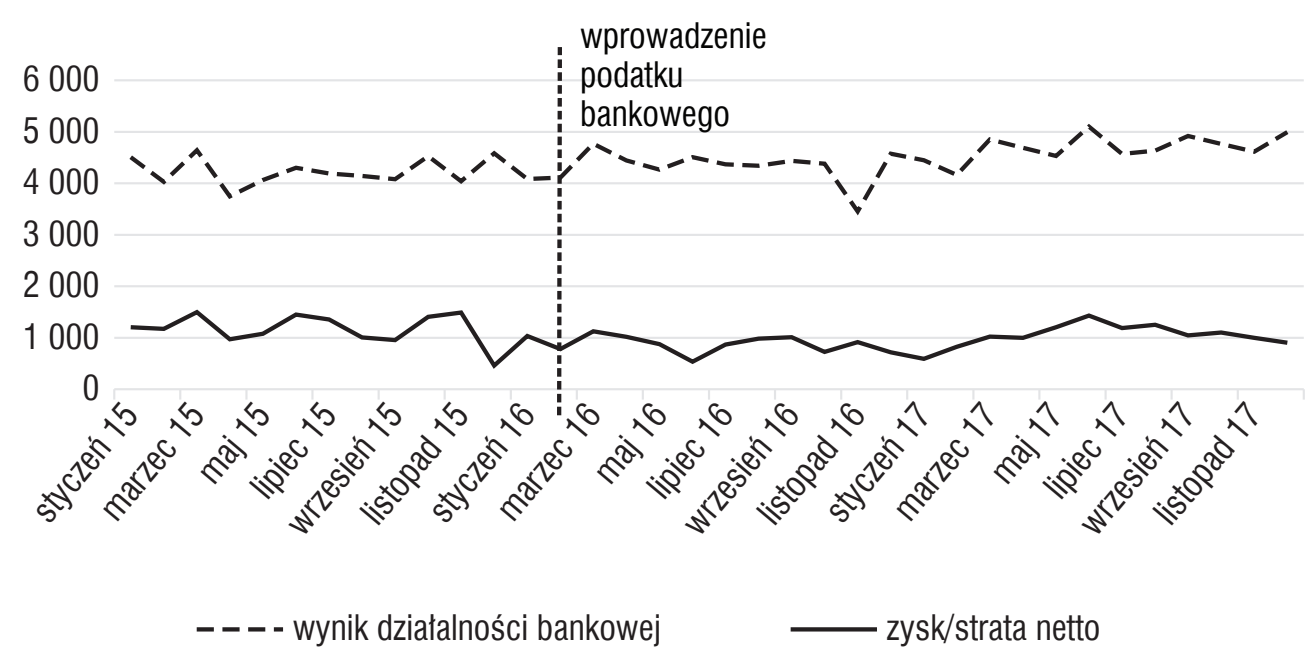

Źródło: KNF.

Podsumowując tę część analizy empirycznej skutków wprowadzenia podatku bankowego w Polsce, należy stwierdzić, że bankom relatywnie skutecznie udało się w ciągu dwóch lat ograniczyć siłę oddziaływania tego instrumentu na wynik bilansowy. Biorąc pod uwage jednocześnie sposób, w jaki dokonały korekty swoich modeli biznesowych (znaczące obniżenie oprocentowania depozytów oraz relatywnie niewielki spadek oprocentowania kredytów), można przyjąć, że analizowana danina nie umożliwiła znaczącej internalizacji negatywnych efektów zewnętrznych.

Analizując sposób oddziaływania wprowadzenia podatku bankowego na wartość i strukturę bilansu i pozycji pozabilansowych banków, warto przede wszystkim przyjrzeć się dynamice głównych składników wpływających na aktywa oraz pasywa banków, czyli odpowiednio kredytom, zakupionym skarbowym papierom wartościowym oraz depozytom. Jak wynika z rysunku 4 opartego na danych Narodowego Banku Polskiego, wprowadzenie analizowanej daniny nie wpłynęło w znaczący sposób na dynamikę akcji kredytowej realizowanej przez banki. Wydaje się, że wiodącym czynnikiem generującym popyt na nowe umowy kredytowe był obserwowany w Polsce w latach 2016-2017 pozytywny trend wzrostu gospodarczego, a banki starały się odpowiadać zarówno na zapotrzebowanie osób fizycznych, jak i podmiotów gospodarczych, moderując ewentualnie zaangażowanie w poszczególne linie biznesowe (np. przesunięcie zaangażowania w bardziej dochodowe kredyty konsumpcyjne 
kosztem niskomarżowych kredytów hipotecznych). W badanej perspektywie czasowej brak jest więc podstaw do stwierdzenia, że wprowadzenie podatku bankowego w istotny sposób wpłynęło na „spłaszczenie” tempa krajowej akcji kredytowej, a tym samym przyczyniło się do znaczącego ograniczenia jej cykliczności.

Rysunek 4. Należności i zobowiązania banków względem przedsiębiorstw niefinansowych oraz pozycja pozabilansowa krajowych banków komercyjnych w latach 2015-2017 (w mln zt)

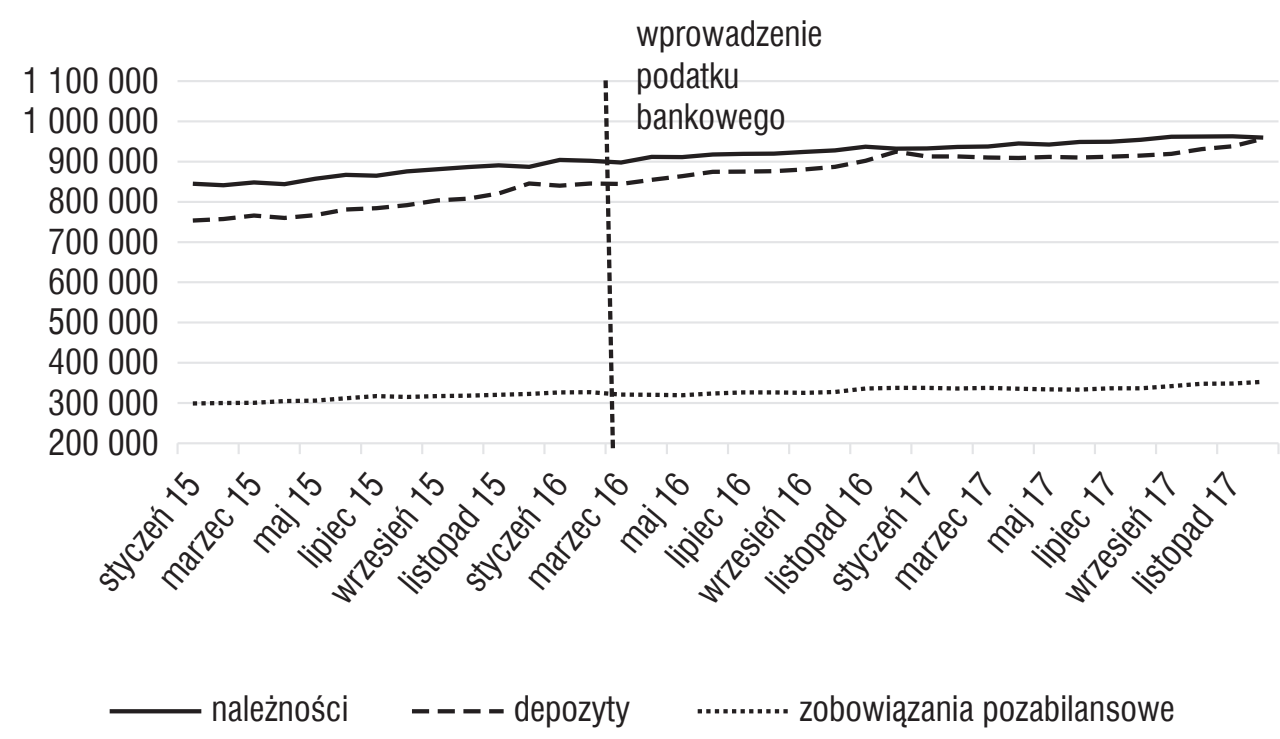

Źródło: NBP.

Warto dodać, że wzrost popytu na papiery skarbowe odbywał się drogą substytucji zainteresowania bonami pieniężnymi NBP oraz stopnia zaangażowania na rynku międzybankowym. Jeśli chodzi o rynek międzybankowy, to wprowadzenie podatku bankowego miało znaczący wpływ na obroty i kwotowania na tym rynku, szczególnie jeśli chodzi o najkrótszą stawkę overnight (rys. 5). Największą zmienność w tym segmencie rynku pieniężnego można było zaobserwować na początku 2016 r., kiedy to banki drastycznie obniżając stawkę WIBID i WIBOR w dniu rozliczenia podatku, starały się zniechęcić swoich kontrahentów do wprowadzania do ich bilansów dodatkowej daniny będącej podstawą do opodatkowania nową daniną. Po adaptacji banków do nowej sytuacji w 2017 r. można mówić o pewnej stabilizacji notowań, jakkolwiek nadal na koniec miesiąca można zaobserwować istotne obniżki rentowności kredytów i depozytów overnight, co prowadzi do znaczących zmian krótkiego końca krzywej dochodowości wykorzystywanej do wyceny większości produktów oferowanych przez banki. 
Rysunek 5. Dzienne notowania stawki WIBOR i WIBID O/N w okresie styczeń 2015 r. - kwiecień 2018 r.

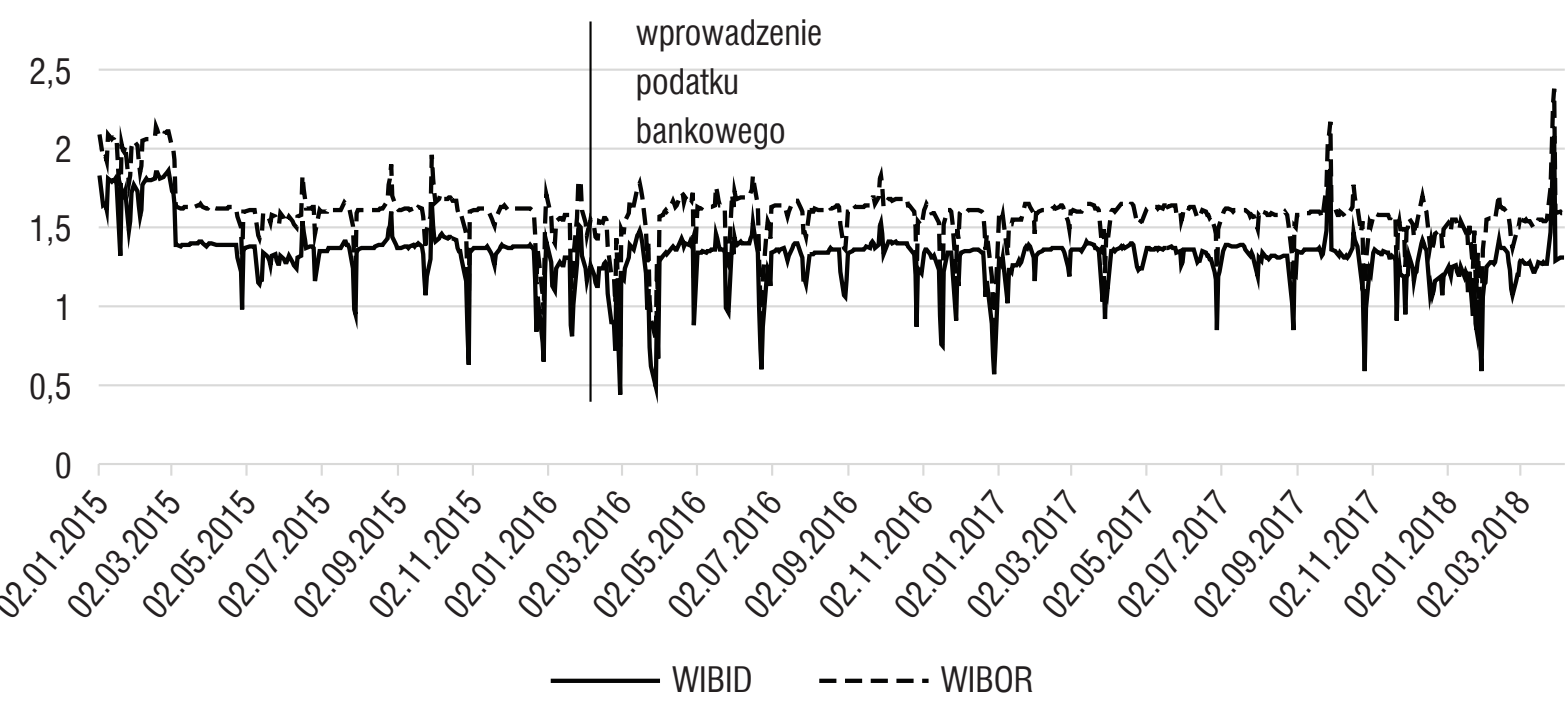

Źródło: stooq.pl

Z punktu widzenia możliwości internalizacji efektów zewnętrznych można więc ocenić, że większe zaangażowanie banków w krajowe papiery wartościowe w pozytywny sposób wpłynęło na ograniczenie ekspozycji banków na ryzyko, nie ograniczając jednocześnie w znaczący sposób dynamiki akcji kredytowej. Pozwoliło jednocześnie na wykształcenie się bardziej stabilnej struktury podmiotów inwestujących w średnio- i długoterminowe skarbowe papiery dłużne, ograniczając możliwość nagłej materializacji ryzyka kursowego oraz ryzyka reputacji/politycznego.

Niepokojący, szczególnie w dłuższej perspektywie, może okazać się wpływ obniżonego oprocentowania depozytów na skłonność klientów, szczególnie osoby fizyczne, do ograniczenia awersji do ryzyka i alokacji posiadanych przez nie środków w objętych znacznie luźniejszymi regulacjami i ochroną finansową podmiotach pozabankowych. Jako dodatkowy negatywny efekt wprowadzenia podatku bankowego można również potraktować destabilizację krótkoterminowego rynku międzybankowego. Trudno obecnie przewidzieć, na ile zdolność do adaptacji krajowych banków pozwoli na minimalizację wpływu tego zjawiska na cały rynek pieniężny.

\section{Analiza wyników badań i konkluzje}

Wprowadzenie w Polsce w 2016 r. podatku bankowego spowodowane było niewątpliwie przede wszystkim przesłankami fiskalnymi. Środki uzyskane z tej daniny 
zasilają bezpośrednio budżet państwa, przy czym jak zostało to wskazane w części empirycznej, wartość zgromadzonych w ten sposób środków jest znikoma w relacji do potencjalnych budżetowych kosztów kryzysu wygenerowanego przez sektor bankowy. Łącznie ze środkami uzyskanymi z procesu uszczelniania poboru pozostałych podatków, obejmującego przede wszystkim poprawę efektywności poboru podatku od towarów i usług, uzyskane przez państwo fundusze pozwalają na większą swobodę w zakresie kształtowania polityk społecznych i socjalnych.

Konstrukcja krajowego podatku bankowego zawiera również rozwiązania, które potencjalnie mogłyby służyć do internalizacji efektów zewnętrznych generowanych przez sektor bankowy. Mowa tu między innymi o możliwości odliczenia od podstawy opodatkowania należności banków stanowiących równowartość środków zainwestowanych w krajowe papiery skarbowe. Analiza danych empirycznych z ostatnich dwóch lat wskazuje, że tego typu rozwiązanie spowodowało istotne zwiększenie zaangażowania krajowych banków w relatywnie bezpieczne instrumenty finansowe, ograniczając tym samym ich ekspozycje na ryzyko kredytowe. Jednocześnie obserwacja danych raportowanych przez banki nie daje podstaw do stwierdzenia, że realokacja części aktywów banków spowodowała znaczące ograniczenie akcji kredytowej. Wręcz przeciwnie, ze względu na ogólną bardzo dobrą koniunkturę gospodarczą wartość kredytów udzielonych przez krajowe banki systematycznie rosła, podatek bankowy może się ewentualnie przyczynić do pewnego ograniczenia tej tendencji, co można również uznać za zjawisko korzystne jako pewnego rodzaju stabilizator cyklicznych wahań akcji kredytowej. Nie zaobserwowano również przewidywanego przez niektórych analityków gwałtownego wzrostu wartości zobowiązań pozabilansowych, które ze względu na charakterystykę używanych w tym zakresie instrumentów finansowych w dłuższej perspektywie mogłyby przyczynić sie do destabilizacji sytuacji banków.

Ocena możliwości pośredniej internalizacji negatywnych efektów zewnętrznych za pomocą podatku bankowego nie jest niestety tak oczywista, jeśli uwzględni się adaptacyjną odpowiedź banków, czyli podjęte przez nie działania z zakresu optymalizacji bankowej. Choć banki nie zdecydowały się na generalne unikanie płacenia daniny, chociażby poprzez księgowe kreowanie wyniku finansowego umożliwiającego wprowadzenie programów naprawczych, to jednak ich znacząca aktywność w zakresie zmiany struktury aktywów oraz pasywów ma swoje konsekwencje w potencjalnej materializacji ryzyka, oddziałującego na pozostałe sektory systemu finansowego oraz na strefę realną. Mowa tu głównie o dwóch efektach: przerzucaniu na klientów kosztów wprowadzonej daniny poprzez zwiększenie marży odsetkowej wynikające z proporcjonalnie większej obniżki odsetek płaconych deponentom oszczędności w stosunku do ceny podstawienia do dyspozycji klientów środków w ramach nowo zawieranych umowach kredytowych oraz o okresowej destabilizacji krajowego rynku 
międzybankowego w odniesieniu do krótkoterminowych depozytów i pożyczek. Wskazane skutki podejmowanej przez banki optymalizacji podatkowej nie pozwalają na jednoznaczną weryfikację w dostępnej pespektywie czasowej postawionej przez autorkę badania hipotezy badawczej. Niewątpliwie są jednak przesłanką do rekomendowania decydentom stałego monitorowania efektów wprowadzenia analizowanej daniny i wprowadzenia do jej konstrukcji korekt pozwalających na ograniczenie możliwości generowania przez banki negatywnych szoków rodzących ryzyko systemowe.

\section{The effects of introduction of bank levy in Poland in the context of possible limitation of negative externalities generated by national bank sector}

The main goal of this article is to present the possibility of internalization of negative externalities generated by banks with bank levy introduced in Poland in the beginning of 2016. The conducted survey considers Polish banks' adaptive response to newly implemented tax (tax optimization) and co-effects of group response materialized on local interbank and sovereign debt markets. Empirical assessment of bank levy introduction and evaluation of its externalities internalization potential was based on statistical data gathered in 2015-2017.

Keywords: negative externalities internalization, bank levy, tax optimization

\section{Literatura}

1. Amaglobeli D., End N., Jarmuzek M., Palomba G., From systemic banking crises to fiscal costs: risk factors, „IMF Working Paper” No. 166, 2015.

2. Borowski J., Jaworski K., Tymoczko D., Wplyw podatku bankowego w Polsce na kredyt dla sektora niefinansowego, „Studia Ekonomiczne. Zeszyty Naukowe UE w Katowicach" nr 287, 2016.

3. Calomiris Ch.W., Mason J.R., Fundamentals, panics, and bank distress during the depression, „American Economic Review” 93(5), 2003, s. 1615-1647.

4. European Commission, Commission outlines vision for taxing the financial sector, http://europa.eu/rapid/press-release_IP-10-1298_en.htm?locale=en, 2010.

5. European Commission, Communication on taxation of the financial sector, Communications of the European Commission, 2010. 
6. European Commission, Taxation of the financial sector, Commission Staff Working Documents, 2010.

7. FOR, Dlaczego nie należy nakładać podatku na aktywa banków?, „Analiza FOR” nr 5, 2010, https://for.org.pl/pl/a/1438, Analiza-52010-Dlaczego-nie-nalezy-nakladac-podatku-na-aktywa-bankow

8. Furman Ł., Podatek od aktywów instytucji finansowych: zagrożenia czy korzyści, „Zeszyty Naukowe Małopolskiej Wyższej Szkoły Ekonomicznej w Tarnowie” nr 33(1), 2017.

9. Gajewski D.J., Podatek bankowy a zjawisko unikania opodatkowania, „Przegląd Ustawodawstwa Gospodarczego" 6(816), 2016.

10. Gajewski D.J., Podatek bankowy w Polsce - wady i zalety, „Analizy i Studia CASP” 1(1), 2016, s. 1-24.

11. Gorton G., Winton A., Financial Intermediation, „NBER Working Paper” 8928, Cambridge, MA 2002.

12. International Monetary Fund, A Fair and substantial contribution by the financial sector, Interim Report for the G20, April 2010.

13. International Monetary Fund, Containing systemic risks and restoring Financial soundness, Global Financial Stability Report, April 2008.

14. International Monetary Fund, Now is the time for fiscal policies for sustainable growth, Fiscal Monitor, April 2015.

15. Juszczyk S., Snarski P., Przegląd potencjalnych podatków i opłat nakładanych na banki w obliczu globalnego kryzysu gospodarczego, „Zeszyty Naukowe SGGW w Warszawie”, „Ekonomika i Organizacja Gospodarki Żywnościowej” nr 93, 2011.

16. KNF, Syntetyczna informacja na temat wpływu podatku od niektórych instytucji finansowych na sytuację banków komercyjnych, 2017, https://www.knf.gov.pl/knf/pl/komponenty/img/Opracowanie_podatek_bankowy_17-08-2017_58323.pdf

17. Lane P.R., The European sovereign debt crisis, „Journal of Economic Perspectives” 26(3), 2012, s. 49-68.

18. Leland H.E., Pyle D.H., Informational asymmetries, financial structure, and financial intermediation, „The Journal of Finance” 32, 1977, s. 371-387.

19. Malinowski D.M., Podatek bankowy - podstawowe założenia, instytucje i skutki jego wprowadzenia, „Przegląd Podatkowy” nr 2(298), 2016, s. 3-4.

20. Ministerstwo Finansów, Sprawozdanie operatywne z wykonania budżetu państwa za styczeń-grudzień 2016 r., Warszawa 2016.

21. Ministerstwo Finansów, Sprawozdanie operatywne z wykonania budżetu państwa za styczeń-grudzień 2016 r., Warszawa 2017.

22. Narodowy Bank Polski, Wybrane aspekty dodatkowego opodatkowania banków w kontekście debaty na forum Unii Europejskiej, 2010, https://www.nbp.pl/systemfinansowy/ banki_aspekty_opodatkowania.pdf

23. Owsiak S., Społeczny wymiar kryzysu - lekcja dla przyszłości, „Biuletyn PTE” nr 2, 2012. 
24. Rothschild M., Stiglitz J.E., Equilibrium in competitive insurance markets: An essay on the economics of imperfect information, "Quarterly Journal of Economics” 95, 1976, s. 629-649.

25. Schweikhard F.A., Wahrenburg M., The internalization of systemic risk: An analysis of bank levy schemes, [materiał zaprezentowany na konferencji EFA], Gothenburg 2013.

26. Sejm, Proces legislacyjny Sejmu VI kadencji, http://orka.sejm.gov.pl/proc6.nf

27. Srivastav A., Hagendorff J., Corporate Governance and Bank Risk-taking, „Corporate Governance: An International Review” No. 24, 2016.

28. Ustawa z dnia 15 stycznia 2016 r. o podatku od niektórych instytucji finansowych, DzU 2016, poz. 68. 